\title{
The Description of Mental Health and Emotional Mental Disorders of Students And Families During Covid-19 Pandemic
}

\author{
Ariani Sulistyorini*, Tutut Pujianto \\ STIKES Karya Husada Kediri, Indonesia \\ Corresponding author: ariani.iqbal@gmail.com
}

\begin{abstract}
Background: The Covid-19 pandemic could have an adverse impact on both physical and psychosocial conditions. Physical distancing encourages a person to be unable to perform activities normally to reduce the likelihood of transmission. Physical distancing must be done by everyone, including students and their families. This condition can lead to feelings of loneliness, boredom, and anxiety. Another impact that society feels is the onset of unrest due to financial condition, employment, and future life plans. Anxiety and anxiety caused by the Covid-19 pandemic resulted in the emergence of mental health problems and emotional mental disorders.
\end{abstract}

Purpose: This study aimed to find out the picture of mental health and emotional mental disorders in students and families during the Covid 19 Pandemic.

Methods: The research design used is a descriptive crossectional. The population in this study was students of Nursing Diploma 3 Study Program STIKES Karya Husada Kediri and his family. Fifty-six students were selected as sample members, through random sampling techniques. The variables in this study were mental health and emotional mental disorders. Data retrieval is carried out from 6 to 20 June 2020, with the instrument Self Reporting Questionnaire (SRQ-29). Descriptive analysis of data is performed with the help of frequency distribution tables.

Results: The results of the study found that there were 2 respondents $(3.6 \%)$ psychological disorders (anxiety and depression), none (0\%) psychoactive disorders/drug use. Research data also shows that there are 5 respondents (8.9\%) psychotic disorders, as well as 16 respondents $(28.6 \%)$ PTSD disorder. Mental health disorders experienced by respondents are emotional mental disorders with symptoms of fear, worry, anxiety, tension and even excessive headaches. Mental health disorders result in impaired daily life activities.

Conclusion: To prevent an increase in the number of people with emotional mental disorders in students and their families, there needs to be educational efforts that contain how to avoid and overcome emotional mental disorders that occur and the need for psychosocial mental health support in students and their families.

Keywords: Mental Health, Emotional Mental Disorders, Pandemic, Covid-19. 
Journal Of Nursing Practice

http://thejnp.org

ISSN: 2614-3488 (print); 2614-3496 (online)

Vol.4 No.1. October 2020. Page.97-106

\section{BACKGROUND}

The Covid-19 pandemic can be affected for anyone, both physically and psychosocially. This covid-19 pandemic is a non-natural disaster that can have a physical and psychological impact on every individual whether it is a positively confirmed individual or in society in general. Especially with the encouragement of physical distancing causes a person to be unable to carry out the usual routine activities and have to keep a distance with family, friends or relatives to reduce the likelihood of transmission. So is the student and his family. This condition can lead to feelings of loneliness, boredom, anxiety. In addition, this condition can cause unrest related to financial condition, employment, and future life. This is at risk of causing mental health problems and emotional mental disorders.

Mental Health according to constitutions Republic of Indonesia number 18 of 2014 is a condition in which an individual can develop physically, mentally, spiritually, and socially so that the individual realizes his or her own abilities, can cope with pressures, can work productively, and is able to contribute to his community. Every aspect and dimension of man needs a good degree of mental health in order to function optimally. While emotional mental disorders are a condition that indicates an individual undergoing an emotional change that can develop into a pathological state if it continues (Rusdi Muslim, 2013)

Corona Disease (Covid-19) is an infectious disease caused by a new type of coronavirus with common symptoms of fever, weakness, cough, seizures and diarrhea, shortness of breath (WHO, 2020; Repici et al., 2020) Covid 19 comes from the word Co which means Corona, Vi For Virus and D for Disease. Transmission from person to person through saliva sparks during coughing and sneezing (droplet) with an incubation period of 1-14 days, where until now the drug and vaccination have not been found.

Since covid-19 was confirmed in December 2019 to August 2020, WHO has recorded 21.817.650 confirmed cases of Covid-19. Of these 772.751 people died, and 14.553.191 patients were declared cured. Meanwhile, in Indonesia, the latest data on the number of positive cases of coronavirus still shows an increase of 1.821 cases so far the total number of confirmation cases in Indonesia reaches 141.370 cases. Of the total confirmed cases, patients recovered also increased by 1.355 people, with the addition of patients recovering from the corona as a whole to 94.103 people. And 57 patients died today. Thus, overall patients died numbering 6.207 people. In Indonesia the province with the highest confirmed cases of coronavirus is in Jakarta with positive cases increasing by 538 with a total of 30.092 , patients recovering experienced an increase of 208 with a total of 19.916, and patients died an increase of 16 people with a total of 1.011 (Kompas.com, 2020).

In Indonesia the 2nd highest corona virus case is in East Java Province, with positive confirmed corona increased by 336 with a total of 28.239 , the recovered patients experienced an increase of 416 with a total of 21.255 people, and the patients who died increased by 14 people with the total to 2.037 people. In east Java itself the area confirmed the highest corona virus cases are in Surabaya with patients confirmed positively corona virus cases that increased by 112 people with a total of 10.774 people, patients recovered increased by 212 people with a total of 7.727 people, while the patients who died increased by 4 people with the total number to 858 people (Kemenkes RI, 2020) .

The Covid-19 pandemic has a profound effect on all aspects of life. Likewise in the world of education that requires changing all teaching methods, from face-to-face (offline) to online. The online learning process is carried out in the hope that students will still get learning even if they have to stay at home. This is in accordance with the circular number 4 of 2020 from the Ministry of Education on the Implementation of Education in the Emergency Period of Corona Virus Desease (Covid-19). As a result not only students are affected but also families. Families and students became concerned about the continuity of 


\section{Journal Of Nursing Practice}

http://thejnp.org

ISSN: 2614-3488 (print); 2614-3496 (online)

Vol.4 No.1. October 2020. Page.97-106

the study process. In addition, students and families are also worried and anxiety in the event of covid-19 transmission. If the management is not immediately carried out, it does not close the possibility that initially students and families are healthy and fine can become physically and psychologically ill in the form of emotional mental disorders. The responses that appeared were various, ranging from anorexia, headache, sleep not comfort, feeling tense, worried or anxiety. Physical distancing also causes daily activities to be disrupted, including student learning activities. Tang Research (2020); Siti Nurjanah (2020) explores the prevalence of post traumatic stress disorder and depression in students quarantined to dormitory showing improvement in symptoms of PTSD and Depression. Dwidiyanti (2018) mentioned about The risk of mental disorders in earthquake victims in Lombok West Nusa Tenggara shows 75 respondents experienced neurosis, 26 respondents experienced symptoms of psychosis and 57 respondents experienced symptoms of PTSD/Post Traumatic Stress Disorder.

The picture of the emotional mental changes of society in general and students in especially as a result of Covid-19 needs to be known in order to be able to do more. One way to get good and relatively inexpensive emotional mental data, easy and effective is to use the Self-Reporting Questionnaire (SRQ) measuring instrument. It is said to be cheap because it can be done in a fairly short time and does not require special human resources to assess it. SRQ is effective because it has a fairly good validity in terms of its sensistivity and specificity. SRQ is a questionnaire developed by who for the screening of psychiatric disorders and research needs that has been conducted in various countries. SRQ is widely used in developing countries and the level of education of its population is still low. In addition, SRQ is also very suitable for use in countries where the population is still largely derived from low socioeconomic levels.

\section{OBJECTIVE}

This study aimed to find out the picture of mental health and emotional mental disorders in students and families during the Covid 19 Pandemic.

\section{METHODS}

This study used a descriptive crossectional design with a large sample of 56 students and their families, sampling was done by Random Sampling method. The research variables are the mental health and emotional mental disorders of students and families. Data retrieval is carried out from 6 to 20 June 2020. The intrusion used in data retrieval is SRQ-29 (Self Reporting Questionnaire). The collected data is then analyzed with the help of a frequency distribution table.

\section{RESULTS}

\section{CHARACTERISTICS OF RESPONDENTS}

\section{DEMOGRAPHIC DATA}

An overview of the demographic condition of respondents becomes an important part of the data collection to know the characteristics of the respondent more. The demographic picture of respondents includes age, gender and occupation in detail in table 1. 


\section{Journal Of Nursing Practice}

http://thejnp.org

ISSN: 2614-3488 (print); 2614-3496 (online)

Vol.4 No.1. October 2020. Page.97-106

Table 1: Characteristics of respondents based on age, gender and work of students and their families in Nursing Diploma 3 Study Program STIKES Karya Husada Kediri (6 to 20 June, 2020)

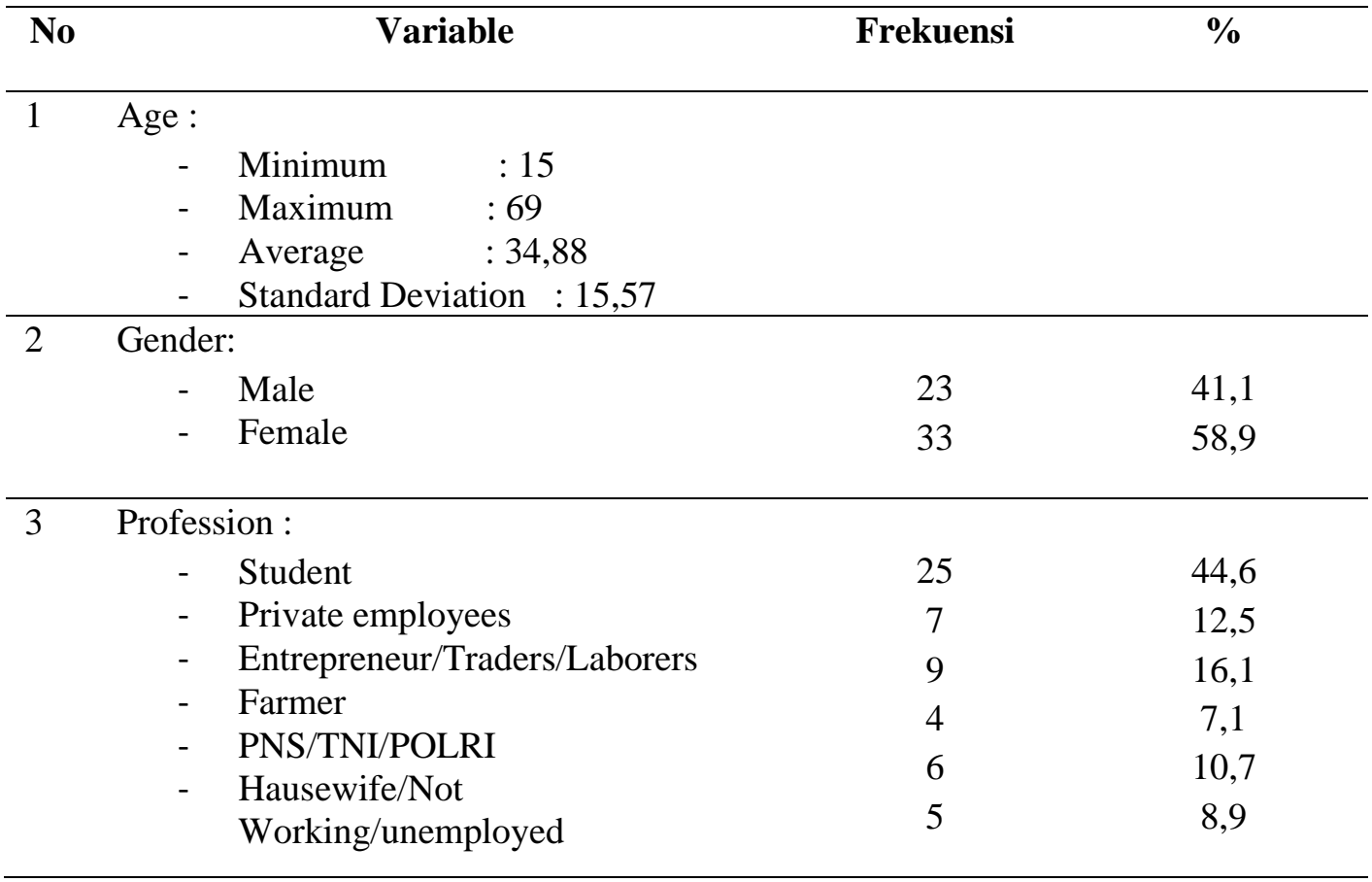

From table 1 above obtained data from 56 respondents Minimum Respondents age of 15 years, maximal age respondents 69 years, average age of respondents 34.88 years. For the sex of 33 respondents $(58.9 \%)$ female, 23 respondents $(41.1 \%)$ male. For jobs 25 respondents $(44.6 \%)$ students, 4 respondents $(7.1 \%)$ as a farmer.

\section{RESPONDENT HISTORY DATA}

The respondent's history is part of the characteristics of the respondent, including the type of symptoms felt, symptoms after traveling, the history of close contact, the history of rapid tests and swab tests. The complete data of the respondent's history is listed in table 2 .

Table 2 : Characteristics of Respondents Based on Student And Family History of Nursing Diploma 3 Study Program STIKES Karya Husada Kediri ( 6 to 20 June, 2020.

\begin{tabular}{cccc}
\hline No & \multicolumn{1}{c}{ Variabel } & Frekuensi & $\%$ \\
\hline 1 & Types of symptoms that are felt & & \\
& $-\quad$ not having/feeling any symptoms & 49 & 87,5 \\
& $-\quad$ cold & 1 & 1,8 \\
& $-\quad$ cough & 1 & 1,8 \\
& $-\quad$ mild Pneumonia & 1 & 1,8 \\
& $-\quad$ chronic diseases & 4 & 7,1 \\
\end{tabular}




\section{Journal Of Nursing Practice}

http://thejnp.org

ISSN: 2614-3488 (print); 2614-3496 (online)

Vol.4 No.1. October 2020. Page.97-106

\begin{tabular}{|c|c|c|c|}
\hline \multirow[t]{3}{*}{2} & Symptoms after traveling & & \\
\hline & - $\quad$ There is & 1 & 1,8 \\
\hline & - There is no & 55 & 98,2 \\
\hline \multirow[t]{3}{*}{3} & Close contact history & & \\
\hline & - ever & 7 & 12,5 \\
\hline & - never & 49 & 87,5 \\
\hline \multirow[t]{3}{*}{4} & Rapid test history & & \\
\hline & - ever & 3 & 5.4 \\
\hline & - never & 53 & 94,6 \\
\hline \multirow[t]{3}{*}{5} & Swab test history & & \\
\hline & - ever & 0 & 0,0 \\
\hline & - $\quad$ never & 56 & 100,0 \\
\hline
\end{tabular}

From table 2 above, of the types of symptoms felt for 30 days during the covid-19 pandemic were 49 respondents $(87.5 \%)$ not having/feeling any symptoms, 4 respondents ( $7.1 \%$ ) have a history of chronic diseases, 1 respondent (1.8\%) feel symptoms such as colds, coughs, mild pneumonia. In the history of symptoms after traveling, 55 respondents $(98.2 \%)$ no symptoms appeared, and 1 respondent $(1.8 \%)$ there are symptoms after traveling.

From a history of close contact with covid patients, 49 respondents $(87.5 \%)$ never close contact, 7 respondents $(12.5 \%)$ there is a history of close contact with the patient. Of the 7 respondents who were in close contact consisted of 2 students, 1 trader, 1 farmer, 1 nurse, 1 private employee and 1 self-employed.

From rapid test history obtained 53 respondents $(94.6 \%)$ never conducted a rapid test, 3 respondents $(5.4 \%)$ have done rapid tests. Of the 3 respondents who had rapid test, consisted of 1 mahasisa, 1 farmer and 1 trader. From the swab test history, all respondents were 56 respondents $(100 \%)$ never do a swab test.

\section{B. SPECIFIC DATA}

Specific data in this study include psychological disorders, psychoactivity, psychotics and PTSD disorders. The specific data of the results of the study on 56 respondents is in full listed in table 3.

Table 3 : Characteristics of Respondents Based on The Picture of Mental Health and Emotional Mental Disorders of Students and Families During the Covid19 Pandemic students and their families, Nursing Diploma 3 Study Program STIKES Karya Husada Kediri, From June 6-20, 2020.

\begin{tabular}{llcc}
\hline No & Variabel & Frekuensi & $\%$ \\
\hline 1 & $\begin{array}{l}\text { psychological disorders (anxiety } \\
\text { depression) } \\
\text { - Yes }\end{array}$ & 2 & 3,6 \\
& - No & 54 & 96,4 \\
\hline $2 \quad$ psychoactive disorders/drug use & & \\
& - Yes & 0 & 0,0 \\
\hline
\end{tabular}




\section{Journal Of Nursing Practice}

http://thejnp.org

ISSN: 2614-3488 (print); 2614-3496 (online)

Vol.4 No.1. October 2020. Page.97-106

\begin{tabular}{|c|c|c|c|}
\hline & - $\quad$ No & 56 & 100,0 \\
\hline \multirow[t]{3}{*}{3} & psychotic disorders & & \\
\hline & - Yes & 5 & 8,9 \\
\hline & - No & 51 & 91,1 \\
\hline \multirow[t]{3}{*}{4} & PTSD disorder (Post traumatic & & \\
\hline & Stress Disorder) & 16 & 28,6 \\
\hline & - Yes & 40 & 71,4 \\
\hline
\end{tabular}

From table 3 above 56 respondents found almost all respondents were 54 respondents (96.4\%) not psychological disorders (anxiety and depression), and 2 respondents $(3.6 \%)$ psychological disorders occured (anxiety and Depression), 56 respondents (100\%) not experiencing psychoactive disorders/drug use, 51 respondents $(91.1 \%)$ no psychotic disorders occurred, 5 respondents $(8.9 \%)$ psychotic disorders, 40 respondents $(71.4 \%)$ no sympton PTSD and 16 respondents (28.6\%) PTSD disorder occurred.

The above disorders occurred after being accompanied by various signs and symptoms that appeared in the respondent. There were nine signs and symptoms felt by respondents during the pandemic period. The signs and symptoms felt by respondents are listed in table 4.

Table 4 : Characteristics of Respondents Based on Signs And Symptoms That Appear

\begin{tabular}{clcc}
\hline No & \multicolumn{1}{c}{ Tanda dan Gejala } & Frekuensi & \% \\
\hline 1. & Headache & 10 & 17,86 \\
\hline 2. & Not sleeping well & 7 & 12,5 \\
\hline 3. & Feeling anxious, tense, or worried & 12,5 \\
\hline 4. & Find it difficult to enjoy daily activities & 16.07 \\
\hline 5. & Easily tired & 7 & 12,5 \\
\hline 6. & $\begin{array}{l}\text { Something is annoying or something out of the } \\
\text { ordinary or yuor mind }\end{array}$ & 3 & 5,36 \\
\hline 7. & $\begin{array}{l}\text { Had heard voices without knowing the source or } \\
\text { that others could not hear }\end{array}$ & 3 & 1,79 \\
\hline 8. & $\begin{array}{l}\text { Experiencing disturbing dreams about a } \\
\text { disaster/calamity or moments as if experiencing } \\
\text { the disaster again }\end{array}$ & 1 & 17,86 \\
\hline 9. & $\begin{array}{l}\text { Interest in friends and the usual activities is } \\
\text { Reduced }\end{array}$ & 10 & \\
\hline
\end{tabular}

From table 4 above obtained $17.86 \%$ experienced signs and symptoms of headache, $12.5 \%$ experienced signs and symptoms of not sleeping well and feeling anxious, tense, or worried, and easily tired, $16.07 \%$ experienced signs and symptoms of Find it difficult to enjoy 


\section{Journal Of Nursing Practice}

http://thejnp.org

ISSN: 2614-3488 (print); 2614-3496 (online)

Vol.4 No.1. October 2020. Page.97-106

daily activities, $5.36 \%$ something is annoying or something out of the ordinary or yuor mind and had heard voices without knowing the source or that others could not hear, $1.79 \%$ experiencing disturbing dreams about a disaster/calamity or moments as if experiencing the disaster again, $17.86 \%$ interest in friends and the usual activities is reduced

\section{DISCUSSION}

The results of the study of 56 respondents, obtained by 54 respondents (96.4\%) psychological disorders (anxiety and depression), 2 respondents (3.6\%) psychological disorders (anxiety and depression), all respondents were 56 respondents (100\%) not experiencing psychoactive disorders/drug use, 51 respondents $(91.1 \%)$ no psychotic disorders occurred and 5 respondents (8.9\%) psychotic disorders, 40 respondents $(71.4 \%)$ no PTSD symptom and 16 respondents (28.6\%) PTSD disorder.

The emotional mental disorders in this study were determined based on data in which if in Quesioner SRQ obtained 5 or more yes answers on questions 1-20, or experienced one or more complaints on questions 22-24, or experienced one or more complaints on questions 25-29. And the number of respondents who experienced emotional mental disorders was 23 respondents $(41.07 \%)$. Emotional Mental Disorders is a state that indicates an individual undergoing an emotional change that can develop into a pathological state if it continues.

Psychological disorders (anxiety and depression) felt by the 2 respondents showed symptoms or complaints that included headaches as many as 10 respondents $(17.86 \%)$, found it difficult to enjoy daily activities 9 respondents (16.07\%), slept unso soundly, felt anxious, tense, or worried and tired as many as 7 respondents (12.5\%). Psychological disorders (anxiety and depression) are caused by students and their families having to stay at home and there are restrictions on all activities including direct oscillation activities with those around them as well as online learning systems for students and students aimed at reducing the risk of transmission or contracting covid-19. These anxious and depressive conditions will affect the respondent's physical and psychological condition. According to the American Psychiatric Association (APA) (2000), when feelings of ansietas appear excessive and significantly impair individual function, they are pathological conditions and are diagnosed as an ansietas disorder in which ansietas disorder centers on irrational experiences and fear or horror that are not proposional so as to elicit both physical and psychological responses. (Patricia G, O'Brien, 2014).

There are several initial symptom responses that occur in response to mental health and psychosocial problems, namely the initial symptoms that include worry, restlessness, panic, fear of losing control, fear of losing control, fear of contracting, irritability, tighter heart palpitations, shortness of breath, shorter and heavier breathing, nausea, bloating and diarrhea, headache, dizziness, itchy skin, tingling, strained muscles, and sleeplessness that lasts for 2 weeks or more (Agustina, 2020). The appearance of anxiety and depression is also possible because some respondents have a history of feeling symptoms similar to covid-19 namely $1.8 \%$ cold, $1.8 \%$ cough, mild pneumonia symptoms $1.8 \%$ and $7.1 \%$ history of chronic disease, history of traveling in pandemic-affected areas, there is a history of close contact as much as $12.5 \%$, and a rapid test history of $5.4 \%$. These factors made respondents feel anxious, fear and depression.

Psychotic disorders experienced by 5 respondents $(8.9 \%)$ is a disturbing feeling or unusual thing in the mind as many as 3 respondents $(5.36 \%)$, have heard a voice without knowing the source or that others can not hear as many as 3 respondents $(5.36 \%)$. Psychosis is a mental disorder characterized by impaired reality. Acute and temporary psychotics are also similar disorders, but are acute disorders and have a better prognosis (Sadock, 2015). At psychiatric examinations on psychotic disorders obtained a general impression of natural 


\section{Journal Of Nursing Practice}

http://thejnp.org

ISSN: 2614-3488 (print); 2614-3496 (online)

Vol.4 No.1. October 2020. Page.97-106

appearance, sad facial romance and sufficient verbal and visual contact, his consciousness is clear, the mood is sad, the afek sad, the harmony seems mismatched (appropiate), on the thought process realistic logical form of thought, coherent thought currents, the contents of preoccupayion tought in the current condition, perception obtained auditoric hallucinations and visual hallucinations, instinctual impulse there is insomnia there is an early type, hypoobuliacence exists, raptus does not exist and psychomotor calm at examination (Yustiana et al, 2019). The signs are also experienced by respondents that there are disturbing feelings up to such as hearing voices that are not sourced,

In this study, PTSD (Post Traumatic Stress Disorder) was the most common disorder in respondents, with 16 respondents $(28.6 \%)$. The perceived PTSD disorder was a decrease in interest in friends and activities that were common as many as 10 respondents $(17.86 \%)$, and 1 respondent (1.79) Experiencing disturbing dreams about a disaster/calamity or moments as if experiencing the disaster again. According to the American Psychiatric Association (2013) PTSD (Post Traumatic Stress Disorder) is a mental condition in which a person experiences panic attacks triggered by the trauma of past experiences. PTSD is also a mental disorder that can develop after exposure to highly threatening or horrific events (Bonanno GA, 2004; Jonathan, 2015: larasuci Arini, 2020). Koenen's study (2017) in the United States on 5.692 respondents, found $82.7 \%$ were exposed to severe and potentially traumatic events, and 8.3 $\%$ of exposed traumas were diagnosed with PTSD. PTSD has clinical manifestations that vary depending on the various factors that affect it including the type of trauma, age, gender, low socioeconomic, education, separation (domestic conflict) trauma before; general childhood difficulties, personal and family psychiatric histories, reporting child abuse, poor social support and initial pretation of reactions to trauma (Jitender, 2020)

\section{CONCLUSIONS}

From the results of the study can be concluded that the impact of covid -19 is at risk of causing mental health problems and emotional mental disorders in the form of psychological disorders, psychotic disorders and PTSD (Post Traumatic Stress Disorder) that are shown by the symptoms that arise, namely headache, find it difficult to enjoy daily activities, sleep unsleal, feel anxious, tense, or worried. easily tired, disturbed mind, never heard the sound without knowing the source, lack of interest, dreams about events / disasters experienced before.

To prevent an increase in the number of emotional mental disorders that occurred in students and their families during the Covid-19 pandemic, education is needed on how to avoid and address emotional mental disorders and the need for Psychosisoal Mental Health Support in students and their families 


\section{Journal Of Nursing Practice}

http://thejnp.org

ISSN: 2614-3488 (print); 2614-3496 (online)

Vol.4 No.1. October 2020. Page.97-106

REFERENCES

Agustina Citra Fitri, dr,SPKJ., 2020, Manajemen Psikososial Pada Penanganan Covid 19, Universitas Yarsi

Dwidiyanti, M.,Hadi, I., Wiguna, R.I., \& Ningsih, H. E. W, (2018), Gambaran Risiko Gangguan jiwa pada Korban Bencana Alam Lombok Nusa Tenggara Barat, Holistic Nursing And Health Science, https://doi.org/10.147/10/hnhs.1.2.2018.82$\underline{91}$

Diatri , (2020), Keparahan dampak fisik dan Pskis Covid 19

Kompas.com, 2020, Update Virus Corona di Dunia 26 Agustus: 24 Juta Orang

Terinfeksi/10 negara dengan kasus Covid -19 terbanyak, https://amp-kompascom.cdn.amproject.org/v/s/amp.kompas.com/tren/read/08/17/095000665

Jitender, Sareen. (2020). Literature Review : Post Traumatic Stress Disorder In Adult: Epidemiologi, pathophysiologi, clinical manifestations, course, assesment, and diagnosis. Retrieved from https;//www.uptodate.com/contents/ posttraumaticstress-disorder-in-adult-epidemiologi-pathophysiologi-clinical-manifestationscourse-asses-ment-and-diagnosis

Kementerian Kesehatan RI, 2020, Pedoman Dukungan Psikososial dan Kesehatan Jiwa pada masa pandemi Covid-19

Koenen KC, Ratanatharathorn A, Ng L, et al, 2017, Post Traumatic Stress Disorder in The World Mental Health Surveys, Psychol Med 2017; 47 : 2260

Larasuci Arini, Setiadi Syarli, 2020, Deteksi Dini Gangguan Jiwa dan Masalah Psikososial Dengan Menggunakan Self Reporting Questioner (SRQ-29), Jurnal keperwatan Muhammadiyah, http://journal.um-surabaya.ac.id/index.php/JKM

Patricia G. O’Brien, 2014, Keperawatan Kesehatan Jiwa Psikiatrik Teori dan Praktik, Penerbit Buku Kedokteran, EGC

Repici Alessandro, MD, at all , 2020, Coronavirus (COVID-19) outbreak: What The Departement of endoscopy Should know, Special Article, Volume 92, issue 1, P192-197, July 01,2020

Rusdi Muslim, Dr.dr.SpKj.,M.Kes , 2013, Buku saku Diagnosis Gangguan Jiwa, Rujukan Ringkas Dari PPDGJ-III dan DSM-5, Bagian Ilmu Kedokteran Jiwa, Universitas Atmajaya , Jakarta

Sadock BJ, Sadock VA, RuizP, 2015,Schizophrenia Spectrum and Other Psychotic Disorders, In Kaplan and Sadock's Synopsis of Psychiatry, New York : Wolters Kluwer, 11 th

Siti Nurjanah, 2020, Gangguan Mental Emosional pada Klien Pandemi Covid 19 Di Rumah Karantina, Jurnal IlmuKeperawatan Jiwa, Volume 3 No. 3, hal 329-334, Agustus 2020 


\section{Journal Of Nursing Practice}

http://thejnp.org

ISSN: 2614-3488 (print); 2614-3496 (online)

Vol.4 No.1. October 2020. Page.97-106

Tang, W.,Hu,T.,Hu,B.,Jin,C.,Wang,G.,Xie,C.,Chen,S.,\& Xu,J .,2020, Prevalence and Correlates of PTSD and depreeesive symstoms one month after outbreak of the Covid-19 epidemic in a sample of home-quarantined Chinese University student. Journal of Affective Disorders.

Undang Undang Republik Indonesia No 18 Tahun 2014

Yustiana, Anastasia Venny, Aryani, Luh Nyoman Alit, 2019, Gangguan Psikotik akibat penggunaan ganja (cannabis): studi kasus, Medicina 2019, Volume 50, Number 2: 400-403 P-ISSN.2540-8313,E-ISSN,2540-8321 